\title{
THE FUTURE OF MEDICAL MARIJUANA: SHOULD THE STATES GROW THEIR OWN?
}

\author{
$\operatorname{ALEX~KREIT}^{\dagger}$
}

\section{INTRODUCTION}

When thirty federal Drug Enforcement Administration (DEA) agents armed with M-16s' burst into a medical marijuana hospice in Santa Cruz, California, on September 5, 2002, arresting the two owners and a wheelchair-bound patient disabled by polio, ${ }^{2}$ they propelled an already contentious debate between the federal government and state leaders to new heights." In response, Santa Cruz officials, who had "cooperated closely" with the hospice for six years, "issued a provocative public challenge" to the DEA by organizing an event to distribute medical marijuana on the steps of City Hall." Mayor Christopher Krohn, who attended the event alongside city council members,

${ }^{\dagger}$ B.A. 2001, Hampshire College; J.D. Candidate 2004, University of Pennsylvania. Special thanks to my mother, Sonia Spindt, for her love and support. I thank Professor C. Edwin Baker, Robert Raich, and Eric Sterling for their help and insightful suggestions and my father, Leonard Kreit, who sent me many useful medical-marijuanarelated articles. I am also grateful to Professor Lester Mazor, whose wisdom and approach to learning continue to inspire me. Finally, I wish to thank everyone on Volume 151 of the University of Pennsyluania Latu Review.

' Gerald F. Uelmen, Pot Got You Confused? You Must Be the DEA, L.A. TIMES, Sept. 25, 2002, at B13.

2 See John Ritter, Pot Raid Angers State, Patients, USA TODAY, Sept. 17, 2002, at 3A (“[The patient] can't understand ... why [DEA] agents kept ordering her to stand up after they saw her crutches and leg braces next to the bed. Then when her blood pressure spiked and she felt chest pains, the agents refused to call an ambulance ....").

Medical marijuana advocates have also run into occasional trouble with state officials. In Colorado, for example, Secretary of State Victoria Buckley refused to count the votes in a medical marijuana initiative after claiming that initiative sponsors had not actually obtained the required signatures and that the initiative was improperly put on the ballot. Peter Blake \& Berny Morson, Voters Will Decide on Marijuana: New Secretary of State Says Her Predecessor Undercounted Petitions, Rocky MTN. News (Denver), Sept. 22,1999 , at 4A. Less than a year later, Buckley's successor found sixty-six uncounted petitions in Buckley's office. Id. Buckley had passed away, but her spokesman said he thought they were there because she had been counting them. Id.

${ }^{4}$ Maria Alicia Gaura, Santa Cruz Officials Fume over Medical Pot Club Bust: DEA Arrests Founders, Confiscates Plants, S.F. CHRON., Sept. 6, 2002, at Al.

"Maria Alicia Gaura \& Matthew B. Stannard, Santa Criz Officials to Defy Feds, Hand. out Mediral Pol at. City Hall, S.F. CHron., Sept. 13, 2002, at A23. 
said that "[c]learly, state law and federal law are on a collision course" and vowed to stand by the hospice until federal law changed." ViceMayor Emily Reilly went even further, calling it "absolutely loathsome... that federal money, energy and staff time would be used to harass people like this."7

The outrage spread quickly from Santa Cruz to other parts of California. Patients organized protests across the state, and "State Attorney General Bill Lockyer protested and demanded a meeting with [U.S. Attorney General John] Ashcroft." Just a few weeks after the Santa Cruz City Hall event, San José Police Chief William Lansdowne removed his officers from the DEA's High Intensity Drug Trafficking Area task force in protest." Officials in other California cities followed San José's lead and asked their police officers to "stop cooperating with federal agents." and Sebastopol had all passed "anti-DEA resolutions."

Tensions between states and the federal government over medical marijuana are not limited to California. Since 1996, nine states have legalized marijuana for medical use, ${ }^{12}$ a figure which is likely to increase in the coming years given the overwhelming support for medical marijuana among voters ${ }^{13}$ and drug policy reform leaders' continuing focus on state ballot initiatives. The systemic problems in changing drug laws through legislatures, particularly at the federal

"Christopher Krohn, Why I'm Fighting Federal Drug Laws from City Hall, N.Y. TIMES, Sept. 21, 2002, at A15.

${ }^{7}$ Ritter, supra note 2; $f$. Gaura, supra note 4 (illustrating the conflict between local government and the federal government, with one Santa Cruz police officer calling the DEA agents "a bunch of babies").

${ }^{8}$ Bob Egelko, Medical Pot Rallies Held Across the State, S.F. CHron., Sept. 17, 2002, at A16.

"Mark Simon, San Jose Cops off DEA Squad: Chief Doesn't Want Them Raiding Pot Clubs, S.F. CHRON., Oct. 10, 2002, at A17.

10 Eric Bailey, Pot Raids Spur Calls to Quit Working with DEA, L.A. TIMES, Nov. 21 , 2002, at B10.

"ld.

12 In addition to California, Alaska, Arizona, Colorado, Hawaii, Maine, Nevada, Oregon, and Washington have all enacted medical marijuana laws. Medical Frequently Asked Questions, Nat'l Org. for the Reform of Marijuana Laws (Dec. 16, 2002), at http://www.norml.org/index.cfim?Group_ID=3387.

${ }^{13}$ See, e.g., Joel Stein, The New Politics of Pot, TIME, Nov. 4, 2002, at 57, 57 (reporting that, according to a Time/CNN poll, eighty percent of adults think medical marijuana should be legal). 
level, ${ }^{14}$ make further local and state initiative efforts even more probable.

On the federal side, early efforts to stop medical marijuana by keeping physicians from recommending the $\operatorname{drug}^{15}$ or obtaining injunctions against medical marijuana dispensaries ${ }^{16}$ have given way to full-blown raids like the one in Santa Cruz. As a candidate, President George W. Bush said he thought the federal government should respect state decisions on medical marijuana. ${ }^{17}$ However, his drug czar John Walters, former DEA chief Asa Hutchinson, and current DEA Administrator John B. Brown III have done just the opposite and intensified federal efforts to suppress marijuana use and fight states that allow medical marijuana. ${ }^{18}$.Walters views marijuana as a "pernicious" drug with "destructive effects" and argues that medical marijuana supporters are involved in a "cynical campaign ... [that] is part of the drug legalization agenda.","

The federal government has also shown renewed interest in bringing criminal charges against particular medical marijuana growers. In February 2003, Ed Rosenthal, a long-time drug policy reform activist who writes for the magazine High Times, was convicted of three federal

${ }^{14}$ See, e.g., Aryeh Y. Brown, Comment, Obscured by Smoke: Medicinal Marijuana and the Need for Representation Reinforcement Revietu, 22 SEATTLE U. L. REV. 175, 178 (1998) (arguing that "the legislative inability to deal with this issue" is so monumental that "people with a medical need for marijuana ... represent a suspect class-a class of people for whom the legislative system can offer no recourse").

${ }_{15}$ See Administration Response to Arizona Proposition 200 and California Proposition 215, 62 Fed. Reg. 6164, 6164 (Feb. 11, 1997) (relying on protecting the "public interest" to justify administrative action revoking any practitioner's registration if she prescribes or recommends marijuana to a patient).

${ }^{16}$ See, e.g., Linda Greenhouse, Justices Set Back Use of Marijuana to Treat Sickness, N.Y. TIMES, May 15, 2001, at A1 (reporting that the Justice Department sought an injunction rather than a criminal prosecution in a medical marijuana case, thereby avoiding a jury trial in a jurisdiction in which nearly three-quarters of the voters supported California's Proposition 215, CAL. HEALTH \& SAFETY CODE $\$ 11362.5$ (West Supp. 2003)). In a civil case, the government can attempt to bypass a jury entirely by moving for summary judgment.

${ }^{17}$ See Spencer S. Hsu, Bush: Marijuana Laus up to States; But GOP Candidate Says Congress Can Block D.C. Measure, WAsH. PosT, Oct. 22, 1999, at B7 ("Bush answered questions about medical marijuana laws by saying, "I believe each state can choose that decision as they so choose."').

${ }^{18}$ See, e.g., Stein, supra note 13, at 57-61 (discussing Walters's efforts to campaign against passage of additional state drug reform measures).

19 John P. Walters, The Myth of "Harmless" Marijuana, WASH. POST, May 1, 2002, at A25. 
counts of marijuana cultivation and conspiracy. ${ }^{20}$ Rosenthal was growing medical marijuana as a designated agent of the city of Oakland. However, district court Judge Charles R. Breyer-who also heard the Oakland Cannabis Buyers' Cooperative case ${ }^{21}$-barred all evidence relating to Proposition $215^{22}$ and Rosenthal's purpose in growing marijuana. Upon learning of the excluded evidence after the trial, five jurors issued a public apology to Rosenthal and called for the conviction to be overturned. ${ }^{29}$ Juror Marney Craig said that convicting Rosenthal was "the most horrible mistake I've ever made in my entire life. And I don't think that I personally will ever recover from this.",24

In the face of continuing federal opposition after a loss in the Supreme Court on the issue of medical necessity, ${ }^{2.5}$ medical marijuana advocates have turned toward arguments concerning limits on federal power and placed the issue at the center of two recent California lawsuits. In one, Santa Cruz hospice founders Valerie and Michael Corral are demanding that the federal government return all items seized during the September 5 raid-including the marijuana-arguing that their activity was purely intrastate and thus beyond federal authority. ${ }^{26}$ In the other case, two patients and two care givers are seeking an injunction to prevent the federal government from arresting or prose-

${ }^{20}$ Dean E. Murphy, furors Who Convicted Marijuana Grotwer Seek New Trial, N.Y. TIMES, Feb. 5, 2003, at Al4. It is interesting to note that criminal charges were brought against Rosenthal but have not been lodged in other medical marijuana investigations, such as that of the Santa Cruz hospice. Singling out for prosecution a highprofile defendant who has committed a common offense indicates there may be political motivations behind the choice. See OtTo Kirchrimime, PoltTiCal Justice: THE USE OF LEGAL PROCEDURE FOR POLITICAL ENDS 46 (1961) (recognizing as a type of political trial "[ $t$ ] he trial involving a common crime committed for political purposes and conducted with a view to the political benefits which might ultimately accrue from successful prosecution").

${ }^{21}$ United States v. Cannabis Cultivators Club, 5 F. Supp. 2d 1086 (N.D. Cal. 1998), roy'd sub nom. United States v. Oakland Cannabis Buyers' Coop., 190 F.3d 1109 (9th Cir. 1999) (per curiam), rev'd, 532 U.S. 483 (2001). For a discussion of this case and its history on appeal, see infra text accompanying notes 72-76, 187-93.

${ }^{22}$ Compassionate Use Act of 1996, CAL. HEALTH \& SAFE1y CODE $\$ 11362.5$ (West Supp. 2003).

${ }^{23}$ Murphy, supra note 20.

${ }^{24}$ Id.

25. See Oakland Cannabis Buyers' Coop, 532 U.S. at 491 (rejecting the medical necessity defense on the basis that such an exception would conflict with the Controlled Substances Act, Pub. I.. No. 91-513, tit. II, 84 Stat. 1236, 1242-84 (1970) (codified as amended at 21 U.S.C. $\$ \$ 801-904$ (2000))).

${ }^{26 \mathrm{i}}$ Maria Alicia Gaura, Pol Co-op Sues After Confiscation: Santa Cruz Group Pushes for Medical Use, S.F. CHRON., Sept. 25, 2002, at A18. 
cuting them for their medical-marijuana-related activity. ${ }^{27}$ The plaintiffs contend that they "exclusively [use] growing equipment, supplies and materials manufactured within the borders of the State of California." 28 The issues in these cases may pose challenging Commerce Clause questions, but a variety of factors indicate it is unlikely they, or any other effort to limit federal power in the case of private medical marijuana distribution, will ultimately succeed."

Medical marijuana proponents who think "the federal government should stay out of the way" ${ }^{, 90}$ should look to state and local distribution schemes as their best opportunity to place their conduct outside federal reach. There are already indications that movement leaders and frustrated local officials view this as the emerging approach. In the 2002 elections, San Franciscans approved a measure directing the city to "study growing and dispensing marijuana for medical purposes in response to federal crackdowns." " Two years earlier, the Maine state legislature considered implementing a program. that would have distributed marijuana confiscated by the State during regular drug arrests to patients. One of the principle supporters of the idea, Cumberland County Sheriff Mark N. Dion, asked, "Shall we as a sovereign state be held hostage by the federal government simply because we intend to treat our sick and afflicted?":2 A similar proposal was included in a defeated 2002 Arizona ballot initiative that featured a number of other drug policy reforms, such as decriminalization of marijuana for recreational use.

${ }^{27}$ Plaintiffs' Memorandum of Law in Support of Motion for Preliminary Injunction at 2, Raich v. Ashcroft, No. 02-4872 (N.D. Cal. filed Oct. 29, 2002) [hereinafter Plaintiffs' Memorandum], available at http://news.findlaw.com/hdocs/docs/drugs/ raichashcrft $102902 \mathrm{mem} . \mathrm{pdf}$.

${ }^{28}$ Id. at 6.

29) See infra Part III (discussing the problems private medical marijuana growers and users face in Commerce Clause arguments).

30 Where Does Your Pot Grow?, S.F. CHRON., July 26, 2002, at A24.

3 Patrick Hoge, Voters Back City Pot Distribution: Measure Would Have S.F. Study Growing, Dispensing Marijuana, S.F. CHRON., Nov. 6, 2002, at A26; see also Rachel Gordon, Initiative Asks Cily to Roll Its Own: Proposal S Could Put S.F. in the Marijuana Business, S.F. CHRON., Oct. 28, 2002, at A13 ("'If the federal government continues to assault, intimidate and close our community-based cannabis clubs, leaving many thousands of our citizens unable to access medicine,... we must have an alternative distribution network prepared to serve their needs,' said San Francisco Supervisor Mark Leno, the measure's chief sponsor,").

32 Carey Goldberg, Maine Sees Medical Use for Its Seized Marijuana, N.Y. TIMEs, Mar. 14, 2000, at A16.

${ }^{93}$ Elvia Diaz \& Christina Leonard, Day After Election, Winners and Losers Alike Make Plans, ARIz. REPUblic, Nov. 7, 2002, at 21 A. 
The response to federal medical marijuana policy, both from private individuals operating legally under state law and those who argue for state-run distribution schemes, poses a distinct set of problems under the new Commerce Clause doctrine. In the two most famous Commerce Clause cases of the last ten years, United States v. Lopez ${ }^{34}$ and United States $v$. Morrison, ${ }^{35}$ the Supreme Court overturned federal statutes that were by and large supported by the states in which they operated. $^{36 i}$ In each case, the challenges were brought by private individuals, not the states themselves. One commentator has referred to the statutes overturned in those cases as "duplicative federal legislation" and has argued that "[t] he Court accomplishes little when it intervenes to protect the states" in such situations." By contrast, the fight over medical marijuana involves conduct that is prohibited by the federal government but affirmatively allowed under state law. Under state or local distribution regimes, government officials themselves would participate in activity that is criminal under federal law.

This Comment looks at the future of the medical marijuana debate by considering federal power under the Commerce Clause to reach state-run medical marijuana distribution under a hypothetical program similar to those proposed in Maine, Arizona, and San Francisco. Part I discusses the history and present state of the modern medical marijuana movement. Part II provides a summary and discussion of federalism principles, in particular the Commerce Clause doctrine. Part III examines the Controlled Substances Act, the federal law which regulates marijuana, as well as the difficulties that face Commerce Clause challenges under existing state medical marijuana laws. Part IV proposes a hypothetical state-run medical marijuana regulatory program and analyzes whether the federal government could constitutionally outlaw such a program. The Comment con-

\footnotetext{
514 U.S. 549 (1995).

${ }^{35} 529$ U.S. $598(2000)$

${ }^{36}$ See infra Part II.C (discussing the federal statutes disputed in Lopez and Morrison).

${ }^{37}$ Susan R. Klein, A Colloquium on Community Policing: Independent-Norm Federalism in Criminal Law, 90 CAL. L. REv. 1541, 1550 (2002). In this insightful piece, Klein notes with respect to Lopez that "a failure at the state level to separately criminalize gun possessions near schools cannot rationally be equated with approval of such conduct" and argues that the problem would have been entirely different " $[\mathrm{h}] \mathrm{ad}$ a state enacted a provision affirmatively exempting such gun possession from criminal proscription or other sanctions (or been willing to state for the Court on the record that it desired that students bring guns to class)." Id . at 1549-50. Indeed, Lopez was originally charged with violating a Texas law forbidding firearm possession on school premises. Lopez, 514 U.S. at 551.
} 
cludes that medical marijuana advocates should focus on enacting regimes run by state or local governments in the future as providing the strongest potential for protection against federal intervention.

\section{A BRIEF History OF FEDERAL AND STATE RESPONSES TO MEDICAL MARIJUANA}

The debate in the United States over the medicinal value of marijuana dates back to the middle of the 1800s." Although there was never a consensus on the extent of its efficacy, marijuana was generally thought to have some therapeutic value and was included in the United States Pharmacopeia until 1941." Marijuana use and distribution, medical or otherwise, was not significantly regulated by the federal government until the Marihuana Tax Act of $1937 .^{40}$ The tax essentially amounted to a prohibition for recreational users who had to pay a fee of $\$ 100$ an ounce, ${ }^{41}$ which was significantly more than the cost of the marijuana itself. On its face, the Act was much more accepting of medical use of marijuana and taxed registered medical marijuana transactions at only one dollar an ounce. ${ }^{42}$ Nevertheless, "the law made medical use of cannabis difficult because of the extensive paperwork required of doctors who wanted to use it." ${ }^{, 3}$ When Congress was considering the Act, the American Medical Association representative objected to it "because he believed that its ultimate effect would be to strangle any medical use of marihuana," ter its enactment, "medical distribution of the drug had all but disappeared."

While effectively eliminated, medical marijuana use and distribution was still technically allowed under the Marihuana Tax Act until

38 See Lester GrinspoOn \& James B. Bakalar, Marihuana, the Forbidden MEDICINE 4-7 (rev. \& expanded ed. 1997) (providing a historical overview of early studies of marijuana's value as a medicine).

39 . at 8 .

40 Pub. L. No. 75-238, 50 Stat. 551, repealed by Comprehensive Drug Abuse Prevention and Control Act of 1970, Pub. L. No. 91-513, $\$ 1101,84$ Stat. 1236, 1292; see Richard J. Bonnie \& Charles H. Whitebread II, The MariHuana Conviction: A History OF MARIHUANa PROHIBITION IN THE UNITEd STATES 154-74 (1974) (discussing the effort to pass the Marihuana Tax Act).

\footnotetext{
${ }^{41} \S 7(\mathrm{a})(2), 50$ Stat. at 554 .

$42 \$ 7(\mathrm{a})(1), 50$ Stat. at 554 .

43 GRINSPOON \& BAKALAR, supra note 38 , at 8.

44 BONNIE \& WHITEBREAD, supra note 40, at 164.

Id. at 175 .
} 
the passage of the Controlled Substances Act (CSA) in 1970." The CSA was passed in large part because President Nixon saw regulation of the drug trade as an opportunity for the federal government to satisfy public demand to get tough on crime. ${ }^{47}$ " $[\mathrm{H}]$ aving won the election on a law-and-order promise, Nixon had to create a federal role in policing street crime." ${ }^{48}$ His aides settled on policing drug use not only because it could be tied to the common problem of street crime, but also because, unlike other local crimes, it involved interstate commerce." It was in this context that marijuana was placed in Schedule I, the CSA category of drugs with a high potential for abuse and no currently accepted medical use.

In the aftermath of the CSA, drug policy reformers began promoting medical marijuana legalization. The idea had already gained renewed interest in the late $1960 \mathrm{~s}$, as dramatic increases in recreational use led many to accidentally stumble upon marijuana's medical utility. $^{52}$ In the late $1970 \mathrm{~s}$ and early $1980 \mathrm{~s}$, thirty-three states passed medical marijuana laws; ${ }^{53}$ however, they were very different than the state legislation disputed today. Instead of allowing large scale use or distribution programs in violation of the CSA, the majority of these state laws established therapeutic research programs that were officially approved by the federal government under the FDA's Investigational New Drug (IND) program. ${ }^{5.4}$ These state programs were disbanded in

${ }^{410}$ Pub. L. No. 91-513, tit. II, 84 Stat. 1236, 1242-84 (1970) (codified as amended at 21 U.S.C. $\$ \$ 801-904(2000))$.

47 See DAN Baum, Smoke And Mirrors: The War on Drugs and the Politicics of FAILURE 13-21 (1997) (discussing the political motivations behind Nixon's efforts to launch a "war on drugs").

Id at 13 .

49. at 15 .

50) 21 U.S.C. $\$ 812(\mathrm{c})$ sched. I (2000).

5812 (b)(1)(A)-(B). The tension between the Schedule I classification of marijuana as having no medical value and the Federal Investigational New Drug programs that allowed very limited medical marijuana use was never explained by the federal government.

522 See GRINSPOON \& BAKALAR, supra note 38, at 13 ("In the 1960s, as large numbers of people began to use marihuana recreationally, anecdotes about its medical utility began to appear, generally not in the medical literature but in the form of letters to popular magazines like Playboy."). Prior to the 1960 s, very few people, aside from those who had studied marijuana, knew of its potential as a medicine. Id.

Id. at 17 .

54 See Nicole Dogwill, Comment, The Burning Question: How Will the United States Deal with the Medical-Marijuana Debale?, 1998 DETROIT C. L. REV. 247, 256-67 (providing a detailed overview of these state programs and their legal relationships to federal law). Other state laws allowed individual physicians to prescribe medical marijuana to patients. Id. at 267-69. These statutes had even less of an impact because they generally 
1986 when the FDA approved the drug Marinol, a synthetic version of one of marijuana's main chemicals, tetrahydrocannabinol, commonly known as THC.

Because of the difficulty states faced in implementing IND programs, a simultaneous effort emerged to allow individual patients access to marijuana. Glaucoma patient Bob Randall was the first to obtain such individualized permission when, entirely as a result of Randall's struggle, the federal government created the "Compassionate IND" program. 56 The program theoretically made it possible for patients to access medical marijuana through their doctors, though the application process was not easy. INDs were never intended to facilitate medical care for individual patients, but rather were designed as a mechanism for pharmaceutical companies to "assure the safety of new drugs. ${ }^{57}$ Because the Compassionate IND program operated under this same structure, it required a level of paperwork and procedural know-how that made it nearly impossible for the average patient or doctor to gain access. By the time the Compassionate IND program was discontinued in March of 1992, there were only thirteen qualified patients. ${ }^{5 / 8}$ Today, the remaining seven patients continue to receive a regular supply of medical marijuana directly from the federal government."

While the IND programs offered assistance to a limited number of patients, medical marijuana advocates did not see the programs as long-term solutions. Instead, most medical marijuana advocates of the 1970 s argued outright to decriminalize marijuana, which, of course, would have made laws specifically covering medicinal use unneces-

contained requirements that were impossible to meet. For example, Louisiana required that the prescribing physician obtain DEA approval in order to dispense marijuana legally under state law. I $d$. at 269.

55. Id. at 255. Although Marinol is currently available, most patients and medical marijuana advocates claim it is not an acceptable substitute for marijuana because it is not nearly as effective in treating most ailments. See GrinsPOON \& BAKALAR, supra note 38, at 38-39 (arguing that marijuana may be preferable to Marinol because THC is only one of many chemicals contained in marijuana and because marijuana is more reliably and quickly absorbed into the bloodstream than Marinol).

56 See Robert C. Randall \& Alice M. O'leary, Marijuana RX: The Patients' FIGHT FOR MEDICINAL POT 104-12 (1998) (discussing the Compassionate IND program's origin as a government response to Randall's activist work).

${ }^{57}$ GRINSPOON \& BAKALAR, supra note 38 , at 20.

id. at 22

59. Should Smoked Marijuana Be a Medical Option Now?, A-Mark Found, at http:// www.marijuanainfo.org/faqs_list2.php?this_cat=119 (last visited May 8, 2003). The other six patients have since died. $I d$. 
sary. In addition to political lobbying efforts, the National Organization for the Reform of Marijuana Laws (NORML) filed an administrative action in 1972 to move marijuana to a more lenient classification under the CSA. ${ }^{\text {it }}$ Initially, the petition sought to remove marijuana from the CSA entirely or, alternatively, to transfer it from Schedule I to Schedule $\mathrm{V}^{62}$ the least restrictive schedule, which covers drugs that have a low potential for abuse and are currently accepted for medical use. $^{63}$ The government refused to hold a hearing on the subject, and NORML sued to force a rulemaking proceeding. ${ }^{64}$ After a complex and lengthy legal battle, hearings were held in 1986 before Administrative Law Judge Francis Young, who concluded that marijuana is "one of the safest therapeutically active substances known to man" and recommended it be placed in Schedule II. ${ }^{i .5}$ Administrator John C. Lawn denied the recommendation one year later, ${ }^{\text {,it }}$ resulting in further litigation until the matter was finally resolved in favor of the DEA in 1994."

After the resolution of NORML's rescheduling petition, the possibility of a medical marijuana system at the federal level was not promising. Advocates adopted a new strategy and, in 1996, placed initiatives on the ballot in California and Arizona to decriminalize medical marijuana under state law, without regard to federal policy. Both initiatives passed, but the Arizona legislature effectively nullified the result in its state by putting prescribing doctors at risk of losing their li-

(in) In the 1970s, marijuana decriminalization was significantly more politically viable than it is today. A 1972 bipartisan presidential commission, formed under the CSA to study marijuana, recommended its decriminalization. BONNIE \& WHITEBREAD, supra note 40, at 270. Although President Nixon rejected the idea, it was embraced by a number of liberal leaders and, ultimately, by President Carter, who backed eliminating federal penalties for possession of up to one ounce of marijuana. Edward Walsh, Cater Endorses Decriminalization of Marijuana, WASH. POST, Aug. 3, 1977, at A1.

'See Nat'l Org. for the Reform of Marijuana Laws v. DEA, 559 F.2d 735, 741-45 (D.C. Cir. 1977) (discussing the history of the administrative action and the initial resulting litigation).

${ }^{62}$ Id. at 741 .

6321 U.S.C. $\$ 812($ b) (5) (A)-(B) (2000).

it Nat'l Org. for the Reform of Marijuana Laws v. Ingersoll, 497 F.2d 654, 654 (D.C. Cir. 1974).

Michatel Isikoff, Administrative Law Judge Urges Medicinal Use of Marijuana, WASH. POST, Sept. 7, 1988, at A2 (quoting Judge Young).

(bi) Marijuana Scheduling Petition, 54 Fed. Reg. 53,767 (Dec. 29, 1989).

67 See Alliance for Cannabis Therapeutics v. DEA, 15 F.3d 1131, 1137 (D.C. Cir. 1994) (denying a petition for review of the Administrator's final order declining to move marijuana to Schedule II of the CSA). 
censes. $^{\text {is }}$ In California, however, in addition to allowing for medicinal use, the law permitted designated caregivers to grow marijuana for pa-

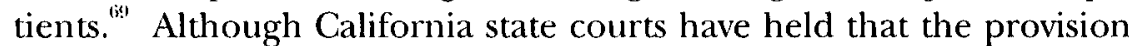
does not shield marijuana dispensaries, ${ }^{70}$ custom and support from local officials have practically legalized the activity for purposes of state law enforcement. ${ }^{71}$ The developing state system has thereby effectively ceded enforcement of all medical-marijuana-related activity, including distribution and growth, to the federal government.

The federal response to California's initiative included strategies aimed at both marijuana dispensaries and physicians. Just over a year after the passage of California's medical marijuana law, the federal government sought to enjoin the cultivation and distribution of marijuana by six different medical marijuana dispensaries. ${ }^{72}$ The Ninth Circuit reversed the district court's order upholding the injunction, finding that the medical necessity defense would likely apply to Oakland Cannabis Buyers' Cooperative's (OCBC) actions. ${ }^{73}$ The Supreme Court reversed, finding that medical necessity was not a valid defense for the manufacture and distribution of marijuana because the legislature itself had "le[ft] no doubt that the defense [was] unavailable."74 The Court did not consider "whether the Controlled Substances Act

"i8 Elvia Diaz, Medical Marijuana Debate Flares, ARIz. RePUBLIC, Oct. 20, 2002, at 7B.

(i: Compassionate Use Act of $1996 \$ 1$, CAL. HEALTH \& SAFETY CODE $\$ 11362.5(\mathrm{~d})$ (West Supp. 2003).

${ }^{70}$ People ex rel. Lungren v. Peron, 70 Cal. Rptr. 2d 20, 31 (Ct. App. 1997).

${ }^{71}$ Local officials in many of California's largest cities and the State Attorney General have shown approval for medical marijuana dispensaries. The City of Oakland declared a city-wide health emergency when the federal government sought to close down the Oakland Cannabis Buyers' Cooperative. United States v. Oakland Cannabis Buyers' Coop., 190 F.3d 1109, 1114 (9th Cir. 1999) (per curiam), rev'd, 532 U.S. 483 (2001).

${ }^{72}$ United States v. Cannabis Cultivators Club, 5 F. Supp. 2d 1086, 1092 (N.D. Cal. 1998), rev'd sub nom. Oakland Cannabis Buyers' Coop., 190 F.3d at 1115 , rev'd, 532 U.S. at 499. By the time the case reached the Ninth Circuit, the Oakland Cannabis Buyers' Cooperative was the only dispensary remaining in the case. $190 \mathrm{~F} .3 \mathrm{~d}$ at 1111 .

190 F.3d at $1114-15$.

${ }^{74} 532$ U.S. at 491 . Though the opinion was technically limited to manufacture and distribution, some dicta suggests that it may also cover use, See, e.g., id. at 493 (rejecting OCBC's argument that the "use of schedule I drugs . . can be medically necessary"). This led Justice Stevens to file a concurring opinion in which he criticized the majority for "suggesting that the defense of necessity is unavailable for anyone under the Controlled Substances Act." Id. at 500-01 (Stevens, J., concurring). "[W] hether the defense might be available to a seriously ill patient for whom there is no alternative means of avoiding starvation or extraordinary suffering is a difficult issue that is not presented here." Id . at 501 (Stevens, J., concurring). 
exceeds Congress' power under the Commerce Clause." ${ }^{\text {,5 }}$ On remand, the district court issued a permanent injunction against OCBC. $^{7}$

In addition to taking action against individual dispensaries, the federal government attempted to effectively block the state law entirely by punishing doctors who recommended marijuana. ${ }^{77}$ Without a doctor's recommendation, it would be impossible for anyone to qualify as a medical user and receive protection under state law. ${ }^{78}$ Shortly after federal officials announced the plan, a group of California doctors and patients filed suit to enjoin its implementation. ${ }^{79}$ Unanimously upholding a district court ruling, the Ninth Circuit permanently enjoined the federal government "from either revoking a physician's license to prescribe controlled substances or conducting an investigation of a physician that might lead to such revocation, where the basis for the government's action is solely the physician's professional 'recommendation' of the use of medical marijuana." The court ruled that the proposed investigations into physician recommendations would threaten expression protected by the First Amendment. ${ }^{81}$ With physicians free to recommend marijuana, shield-

75. Id. at 495 n.7.

${ }^{76}$ United States v. Cannabis Cultivator's Club, Nos. C 98-00085 CRB to -00088 CRB, -00245 CRB, 2002 U.S. Dist. LEXIS 10660, at *9 (N.D. Cal. June 10, 2002).

${ }_{77}$ See Administration Response to Arizona Proposition 200 and California Proposition 215, 62 Fed. Reg. 6164, 6164 (Feb. 11, 1997) ("DEA will seek to revoke the DEA registrations of physicians who recommend or prescribe Schedule 1 controlled substances.").

${ }^{78}$ See Conant v. Walters, 309 F.3d 629, 646 (9th Cir. 2002) (Kozinski, J., concurring) ("The federal government's attempt to target doctors-eliminating the only viable mechanism for distinguishing between legal and illegal drug use-is a back-door attempt to "control or influence the manner in which States regulate private parties." (quoting Reno v. Condon, 528 U.S. 141, 150 (2000))).

7.) li. at 633 .

80) Id. at 632. Judge Kozinski noted this was a "highly unusual exercise of discretion in enjoining the federal defendants from even investigating possible violations of the federal criminal laws." Id. at 640 (Kozinski, J., concurring).

Id. at 637; see id. ("Moreover, the policy does not merely prohibit the discussion of marijuana; it condemns expression of a particular viewpoint, i.e., that medical marijuana would likely help a specific patient."). In his concurrence, Judge Kozinski noted that in addition to the First Amendment rights of patients, federalism concerns were central to his opinion of the case.

I believe the federal government's policy runs afoul of the "commandeering" doctrine announced by the Supreme Court ... . Applied to our situation, this means that, much as the federal govermment may prefer that California keep medical marijuana illegal, it cannot force the state to do so. Yet, the effect of the federal government's policy is precisely that ....

ld. at 645-46 (Kozinski, J., concurring) (citations omitted). 
ing those who receive recommendations from prosecution under state law, the DEA has been left with the daunting task of attacking the California medical marijuana system on a case-by-case basis.

Medical marijuana advocates have enjoyed tremendous success at the state level since $1996,{ }^{42}$ but they continue to have difficulty changing or finding ways to exempt their activity from federal law. Shortly after the passage of Proposition 215, Congress passed a "sense of the Congress" resolution in opposition to medical marijuana; ${ }^{83}$ and, given the Bush administration's hostility toward medical marijuana, ${ }^{84}$ federal efforts to circumvent state medical marijuana laws will likely continue. Nonetheless, the Ninth Circuit's holding in Conant v. Walters severely limits the ease with which the federal government can achieve these goals. Because the DEA is unlikely to target medical marijuana users themselves, ${ }^{8,5}$ state medical-marijuana-decriminalization measures can prove useful to some patients despite federal limitations on distribution and manufacture. At the same time, however, these state laws offer little help to patients who cannot obtain marijuana from the black market or cultivate their own. Often, procuring marijuana through such means is difficult due to the severity of the illness. ${ }^{8 i}$ Without reli-

"82 Prior to the 2002 election, "[m]edical marijuana initiatives had won in all eight states where they had been on the ballot." Ethan Nadelman, The Hospice Raid and the War on Dmugs, SAN DIEGo UNION-TRIB., Sept. 19, 2002, at B13. In the 2002 election, an Arizona ballot measure to establish distribution of state-seized marijuana for medical purposes was rejected. Diaz \& Leonard, supra note 33. This has been the only state medical marijuana initiative to fail; however, Arizona voters have already approved a medical marijuana initiative permitting individual use, although state lawmakers "effectively nixed its use by putting doctors at risk of losing their licenses for prescribing it." $I d$

Act of Oct. 21, 1998, Pub. L. No. 105-277, div. F, 112 Stat. 2681, 2681-760.

${ }^{8.4}$ For recent examples of the federal government's attempts at combating medical marijuana, see supra Introduction.

The DEA's limited resources make it practically impossible for its officers to enforce minor possession laws without extensive cooperation from state police. Additionally, the potential for public backlash militates against plans to go after medical marijuana users. See, e.g., William Claibome \& Roberto Suro, Medicinal Marijuana Brings Legal Headache, WASH. POST, Dec. 5, 1996, at Al ("Federal agencies have the law behind them but ... with limited resources, their focus would remain on major traffickers." (citing statements made by Thomas A. Constantine, DEA Administrator from March 1994 to July 1999)). But of. Marijunna Grower Sentenced to 27 Months, L.A. TIMES, Aug. 7, 1999, at A21 (telling the story of B.E. Smith, an outspoken proponent of Proposition 215 who was convicted of felony marijuana possession and cultivation after being accused of growing marijuana on federal land).

See Declaration of Martin Martinez at 3, United States v. Cannabis Cultivator's Club, No. 98-00088, 2002 U.S. Dist. LEXIS 10660 (N.D. Cal. June 10, 2002) ("It is not practical for a severely disabled person to run around the streets looking for a safe and reliable source of illegal cannabis."). 
able methods of distributing medical marijuana, state medical marijuana laws are often least effective for the primary population they are designed to help.

For these reasons, efforts to avoid federal regulation and to establish reliable distribution programs continue even in areas where state and local law affords private marijuana distributors significant protection. ${ }^{87}$ Short of changing federal law, recent Commerce Clause cases provide the best opportunity for the establishment of a completely legal medical marijuana distribution system. If successful, a Commerce Clause challenge might allow state-approved distribution systems to operate free of federal interference. The following Part reviews the current state of Commerce Clause doctrine to provide a context in which the potential for such a challenge can be analyzed.

\section{Federal Power and States' Rights}

\section{A. Commerce Clause}

In 1937, the Supreme Court upheld the National Labor Relations Act as a constitutional exercise of Congress's Commerce Clause power to regulate interstate commerce. 88 The decision marked a dramatic shift away from the previous "direct-indirect" Commerce Clause standard, ${ }^{89}$ under which key pieces of President Roosevelt's New Deal were struck down,, 0 and toward a more "practical conception of the commerce power." This practical conception focuses on whether there is

${ }^{87}$ San Francisco, for example, has given incredible support to private dispensaries that operate within the city. The San Francisco District Attorney was given an award for his "courage and leadership" on the medical marijuana issue. Jonathan Curiel, ProMarijuana Group Honoring S.F.'s Hallinan: Auard Will Be Named for D.A., S.F. CHRON., June 9, 2000, at A21. However, the relative ease with which patients can currently obtain marijuana in San Francisco did not stop voters from passing a 2002 proposition in favor of a city-run program better positioned to avoid federal regulation. See generally Hoge, supra note 31 (reporting the passage of the 2002 measure and its details).

NLRB v. Jones \& Laughlin Steel Corp., 301 U.S. 1, 43 (1937).

(N) C. A.I.A. Schechter Poultry Corp. v. United States, 295 U.S. 495, 548-49 (1935) (characterizing the "direct-indirect" standard as "a fundamental one, essential to the maintenance of our constitutional system," and holding that Congress could not constitutionally set minimum-wage and maximum-hour laws because they were only indirectly related to cost and prices).

(5) The Court had so frustrated President Roosevelt that he proposed adding new Justices in what was popularly called his court-packing plan. See generally Alpheus Thomas Mason, Horlan Fiske Stone and FDR's Cont Ilan, 6I YAL.E L.J. 791 (1952) (examining Roosevelt's court-packing plan).

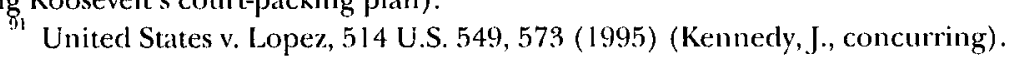


a rational basis for finding that the regulated activity, in the aggregate, substantially affects interstate commerce. ${ }^{92}$

The implications of the Court's new standard became clear in Wickard $v$. Filburm, decided in 1942." Filburn, a wheat farmer, sought to enjoin the government from enforcing against him the Agricultural Adjustment Act of $1938,{ }^{34}$ which aimed to stabilize the price of wheat by regulating its intrastate production. ${ }^{9.5}$ Filburn exceeded his acreage allotment, using the additional wheat to feed his livestock and to produce home-consumed flour. ${ }^{6 / 6}$ The Court held that applying the Act to Filburn was a lawful exercise of congressional power under the Commerce Clause, even though it covered "production not intended in any part for commerce but wholly for consumption on the farm" and the "[p]enalties $d[i d]$ not depend upon whether any part of the wheat, either within or without the quota, [was] sold or intended to be sold." ${ }^{97}$ The Court argued that regulating intrastate activity like Filburn's was vital to the proper functioning of Congress's regulation of national wheat prices and that such activity, in the aggregate, had a substantial effect on interstate commerce. ${ }^{98}$ If every farmer were allowed to produce unlimited supplies of wheat for personal consumption, the government would not have been able to raise the price of wheat in the national market. ${ }^{99}$

Even after Wickard, the Court occasionally relied on other theories in Commerce Clause cases, such as whether an item had moved in interstate commerce. In United States $v$. Sullivan, the Court upheld the conviction of a pharmacist for selling a total of twenty-four pills on two separate occasions without statutorily required directions for use or warnings of danger. ${ }^{1 \%}$ The Court found it was within the Commerce Clause power "to regulate the branding of articles that have completed an interstate shipment and are being held for future sales in purely local or intrastate commerce" because the articles had moved

Id. at 600 (Thomas, J., concurring).

317 U.S. 111 (1942).

7 U.S.C. $\$ \$ 1281-1393(2000)$.

317 U.S. at 113.

Id. at 114 .

97 Id. at $118-19$.

See id. at 127-28 ("That [Filburn's] own contribution to the demand for wheat may be trivial by itself is not enough to remove him from the scope of federal regulation where, as here, his contribution, taken together with that of many others similarly situated, is far from trivial.").

Id. at $128-29$.

1(ix) 332 U.S. 689, 691-92 (1948). 
in interstate commerce. ${ }^{101}$ Wickard's aggregation principle, in combination with the substantial effects doctrine, seemed to give Congress almost limitless power under the Commerce Clause, and for over fifty years every statute faced with a Commerce Clause challenge was upheld. $^{102}$

\section{Lopez: Defining Limits to the Commerce Power}

The Supreme Court abandoned its liberal approach to federal power under the Commerce Clause in 1995 with its five-to-four decision in United States v. Lopez, in which it held part of the Federal GunFree School Zones Act of 1990 (GFSZA) unconstitutional. ${ }^{103}$ The GFSZA made gun possession in a school zone, defined as within one thousand feet of a school, ${ }^{104}$ a federal criminal offense. ${ }^{105}$ Lopez, a twelfth-grade student, brought a .38-caliber gun to school, which was found by school officials acting on an anonymous tip. ${ }^{106} \mathrm{He}$ was arrested by the police and charged originally under state law. ${ }^{107}$ The next day, state charges were dismissed and Lopez was charged, and ultimately convicted, under section 922 (q) of the GFSZA. ${ }^{\prime \prime \prime}$ Lopez appealed on the grounds that section $922(q)$ was beyond the limits of Congress's Commerce Clause power. ${ }^{109}$

Chief Justice Rehnquist, writing for the majority, began his analysis by giving a historical overview of important Commerce Clause decisions. He concluded that the cases revealed "three broad categories of activity that Congress may regulate under its commerce power."

First, Congress may regulate the use of the channels of interstate commerce. Second, Congress is empowered to regulate and protect the instrumentalities of interstate commerce, or persons or things in interstate commerce, even though the threat may come only from intrastate activities. Finally, Congress' commerce authority includes the power to regu-

101 Id. at 698 .

${ }^{102}$ See, e.g., United States v. Taylor, 226 F.3d 593, 598 (7th Cir, 2000) (“From 1937 to 1995 , the Supreme Court consistently upheld federal legislation against claims that Congress had overstepped its authority under the Commerce Clause.").

I013 514 U.S. 549, 567-68 (1995).

10.4 U.S.C. $\$ 921$ (a) (25) (2000).

$105 \$ 922(\mathrm{q})(2)(\mathrm{A})$.

1165514 U.S. at 551.

${ }^{107} / d$.

$108 \mathrm{Id}$.

109! $l d$. at 552 .

${ }^{110}$ Id. at 558 . 
late those activities having a substantial relation to interstate commerce, i.e., those activities that substantially affect interstate commerce. ${ }^{111}$

Rehnquist emphasized that the proper standard for the final category was not merely whether an activity affects interstate commerce, but whether it substantially affects interstate commerce. ${ }^{12}$

The Court quickly concluded that section 922(q) could not be defended under either of the first two categories and turned its analysis to the third. ${ }^{13}$ Rehnquist then further divided the third category into two subcategories-economic activity and noneconomic activity ${ }^{114}$ indicating that, while legislation regulating economic activity would always be sustained as a valid exercise of commerce power, ${ }^{115}$ noneconomic activity would be subject to a more stringent review. ${ }^{116}$ Rehnquist concluded that possession of a gun in a school zone was a criminal act that "by its terms has nothing to do with 'commerce' or any sort of economic enterprise, however broadly one might define those terms." 117 The Court did not detail what level of effect would be needed to meet the "substantial effects" test for noneconomic activity but criticized the statute for its lack of congressional findings, which "would [have] enable[d] [the Court] to evaluate the legislative judgment that the activity in question substantially affected interstate commerce." The Court then discussed the government's arguments concerning the ways in which gun possession in a school zone affects

III Id. at 558-59 (citations omitted).

112 See id. at 559 (concluding that, while the "case law has not been clear whether an activity must 'affect' or 'substantially affect' interstate commerce," the "proper test requires an analysis of whether the regulated activity 'substantially affects' interstate commerce").

111 Id.

114 Id. at $559-61$.

115 See id. at 560 ("[T] he pattern is clear. Where economic activity substantially affects interstate commerce, legislation regulating that activity will be sustained.").

${ }^{116}$ See id. at 561 (arguing that previous Commerce Clause cases involved economic activity and therefore more likely involved valid exercise of congressional power). The Court seemed to imply that, unlike noneconomic activity, economic activity would always have a substantial effect on interstate commerce when aggregated:

Section $922(q)$ is not an essential part of a larger regulation of economic activity, in which the regulatory scheme could be undercut unless the intrastate activity were regulated. It cannot, therefore, be sustained under our cases upholding regulations of activities that arise out of or are connected with a commercial transaction, which viewed in the aggregate, substantially affects interstate commerce.

Id.<smiles></smiles> 
interstate commerce and concluded that the link was too attenuated. $^{119}$ In addition to these criticisms, the Court faulted section 922(q) for lacking a jurisdictional element, such as a requirement that the gun have moved in interstate commerce, "which might limit its reach to a discrete set of firearm possessions that additionally have an explicit connection with or effect on interstate commerce."120

The Court also argued that upholding the statute would allow Congress to regulate areas traditionally left to the states. "Under the theories that the Government presents in support of $\$ 922(q)$, it is difficult to perceive any limitation on federal power, even in areas such as criminal law enforcement or education where States historically have been sovereign." ${ }^{121}$ Rehnquist argued that accepting the federal government's arguments would also allow Congress to regulate the curriculum of local schools $^{122}$ and said that the Commerce Clause power "does not include the authority to regulate each and every aspect of local schools." 23 In his concurrence, Justice Kennedy relied heavily on the notion that education was a traditional area of state concern. He believed that, because the proximity to schools, "including of course schools owned and operated by the States ..., is the very premise for making the conduct criminal," the Court has "a particular duty to ensure that the federal-state balance is not destroyed."124

\section{Morrison: Not Just a Misstep}

Whether Lopez represented a true change in the Court's view of Commerce Clause doctrine was not immediately apparent. In his dissent in Lopez, Justice Souter wondered whether the decision was "an epochal case" or "only a misstep." The Court's decision in United States $v$. Morrison ${ }^{121 i}$ showed that, at the very least, Lopez was not an anomaly.

119 Id. at 563-64; see also id. at 567 ("To uphold the Government's contentions here, we would have to pile inference upon inference in a manner that would bid fair to convert congressional authority under the Commerce Clause to a general police power of the sort retained by the States.").

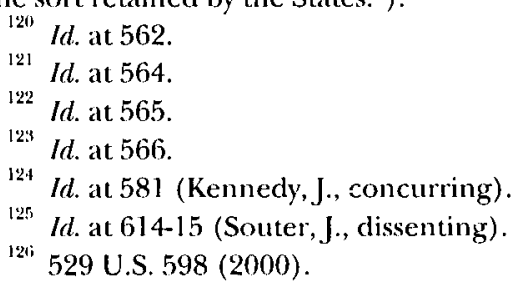


Christy Brzonkala, a student at Virginia Polytechnic Institute (Virginia Tech), claimed that another student, Antonio Morrison, raped her and made statements that demonstrated a gender motivation for the attack. ${ }^{127}$ Brzonkala filed a complaint against Morrison under Virginia Tech's disciplinary policy, at which time Morrison admitted to raping her. ${ }^{128}$ The school punished him with a two-semester suspension, but after an appeal, another conviction, and another appeal, Virginia Tech set aside the punishment. ${ }^{129}$ Brzonkala then filed a federal civil suit under section 13981 of the Violence Against Women Act of 1994 (VAWA), which provided a private cause of action for victims of gender-motivated violent acts. ${ }^{130}$ Morrison challenged section 13981 as unconstitutional federal legislation. ${ }^{131}$

The Court first restated the three separate categories properly subject to regulation under the Commerce Clause power outlined in Lopez and noted that section 13981 fell into the "substantial effects" category. ${ }^{132}$ The Court then noted that "the noneconomic, criminal nature of the conduct at issue was central" to Lopez ${ }^{133}$ and, after observing that section 13981 had no jurisdictional element, ${ }^{194}$ found that "[g]ender-motivated crimes of violence are not, in any sense of the phrase, economic activity." ${ }^{295}$ The most remarkable difference between the statute in Lopez and section 13981 was that section 13981 included extensive congressional findings that gender-motivated violence affected interstate commerce by, among other things, discouraging potential victims from interstate travel and increasing medical costs. ${ }^{196}$ Although stopping short of adopting "a categorical rule against aggregating the effects of any noneconomic activity,"137 the majority rejected the effects found by Congress because they could only be reached through a "but-for causal chain from the initial oc-

${ }^{127}$ ld. at 602 .

Id. at 603 .

12!3 $I d$.

1311 42 U.S.C. $\$ 1.3981$ (c) (2000).

131529 U.S. at 604.

132 Id. at 608-09.

${ }^{133}$ Id. at 610 .

${ }^{134}$ Id. at 613 . A jurisdictional element would require a tie to interstate activity as an element of the offense and would "lend support" to the argument that a given statute is sufficiently tied to interstate commerce. $I d$.

$135 \mathrm{ld}$.

131) See id. at 614 ("In contrast with the lack of congressional findings that we faced in Lopez, $\$ 13981$ is supported by numerous findings regarding the serious impact that gender-motivated violence has on victims and their families.").

137 Id. at 613. 
currence of violent crime (the suppression of which has always been the prime object of the States' police power) to every attenuated effect upon interstate commerce." Morrison therefore made clear both that Lopez did not turn on the lack of congressional findings and that the Court would not automatically accept such findings. ${ }^{199}$ The Court also noted the importance of maintaining a "distinction between what is truly national and what is truly local." no better example of the police power, which the Founders denied the National Government and reposed in the States, than the suppression of violent crime and vindication of its victims."141

\section{B. The Tenth Amendment}

The notion, expressed in Lopez and Morrison, of protecting traditional areas of state authority from federal intrusion draws heavily from some of the Court's Tenth Amendment cases and cannot fully be appreciated without an understanding of them. In Maryland $v$. Wirtz, $^{142}$ the Court had the opportunity to consider whether state operation of an institution had any impact on regulation of the institution under the Commerce Clause. In 1961, Congress extended minimum-wage and maximum-hour laws under the Fair Labor Standards Act to state-run enterprises such as hospitals and schools. ${ }^{143}$ While the standards had already been upheld as applied to private companies, ${ }^{144}$ Maryland argued that the commerce power did not afford a basis to extend them to schools and hospitals operated by the states. ${ }^{145}$ The Court upheld the statute, stating that it "[would] not carve up the commerce power to protect enterprises indistinguishable in their effect on commerce from private businesses, simply because those enterprises happen to be run by the States for the benefit of their citi-

Iss ld. at 615 .

[3!) See id. at 614 ("[T] he existence of congressional findings is not sufficient, by itself, to sustain the constitutionality of Commerce Clause legislation.").

(4). at $617-18$.

1.4. Id. at 618 .

1.12 392 U.S. 183 (1968), overruled by Nat'l League of Cities v. Usery, 426 U.S. 833 (1976), overruled by Garcia v. San Antonio Metro. Transit Auth., 469 U.S. 528 (1985).

1.4. $I$. at $186-87$.

1.4 See United States v. Darby, 312 U.S. 100, 121 (1941) (upholding a policy of "excluding from interstate commerce all goods produced for the commerce which do not conform to the specified labor standards").

145. Wirtz, 392 U.S. at 193. 
zens." ${ }^{146}$ At the same time, some of the opinion's language seemed to hedge this broad holding. The Court was careful to note:

The Act establishes only a minimum wage and a maximum limit of hours unless overtime wages are paid, and does not otherwise affect the way in which school and hospital duties are performed. Thus appellants' characterization of the question in this case as whether Congress may, under the guise of the commerce power, tell the States how to perform medical and educational functions is not factually accurate. ${ }^{1+7}$

The holding seemed to imply that the Court would be less accepting of a federal law that regulated state schools or hospitals in a more substantive way.

Although not mentioned by the majority in Wirtz, the Tenth Amendment served as the basis for Justice Douglas's dissent, in which he argued that the regulations violated federalism principles protected by the Tenth Amendment. ${ }^{148}$ The Tenth Amendment was also the foundation for the Court's opinion in National League of Cities $v$. Usery, ${ }^{14: 1}$ which overturned Wirtz ${ }^{150}$ on incredibly similar facts. As in Wirtz, the Usery Court found that the subject matter Congress sought to regulate fell undeniably within its Commerce Clause power. ${ }^{151}$ However, it held that the Tenth Amendment itself prevented these otherwise valid regulations from extending to the state-run entities. ${ }^{152}$ This was an interesting theory with broad implications, but before elaborating much further on it, the Court abandoned it entirely in the 1985 case of Garcia v. San Antonio Metropolitan Transit Authority. ${ }^{153}$ In Garcia, the Court held that the Tenth Amendment did not shield states from otherwise valid acts of Congress pursuant to the Commerce Clause. ${ }^{154}$ Under this view, the Tenth Amendment seems in

${ }^{140^{\circ}}$ Id. at $198-99$

${ }^{147}$ Id. at 193

${ }^{148}$ See id. at 201 (Douglas, J., dissenting) ("[W]hat is done here is nonetheless such a serious invasion of state sovereignty protected by the Tenth Amendment that it is in my view not consistent with our constitutional federalism.").

${ }_{149} 426$ U.S. 833 (1976), overruled by Carcia v. San Antonio Metro. Transit Auth., 469 U.S. 528 (1985).

${ }^{150}$ Id. at 855 .

151 Id. at 841 .

${ }^{152}$ See id. at 852 ("[T] he dispositive factor is that Congress has attempted to exercise its Commerce Clause authority to prescribe minimum wages and maximum hours to be paid by the States in their capacities as sovereign governments.").

453 U.S. 528 (1985).

${ }^{154}$ See id. at 550 ("With rare exceptions, like the guarantee, in Article IV, $\S 3$, of state territorial integrity, the Constitution does not carve out express elements of state sovereignty that Congress may not employ its delegated powers to displace."). 
many ways to be nothing more than a truism, reiterating that if a power is not expressly granted to the federal government in another part of the Constitution then it is left to the states. ${ }^{155}$ This theory has prevailed after Garcia, and, as a result, the issue of how to interpret federal powers enumerated in the Constitution has become increasingly important in the debate about federalism that was formerly carried on in Tenth Amendment decisions. The scope of Congress's Commerce Clause power, which was central to Wirtz, Usery, and Garcia, is thus all the more significant to considerations of states' rights.

\section{Important Themes in the New Commerce Clause Doctrine}

According to one commentator, "[p]erhaps the most striking feature of the Rehnquist Court's jurisprudence has been the revival over the last 5-10 years of doctrines of constitutional federalism." striking, the Court's revival of the Commerce Clause doctrine has also come without expressly overturning old law or announcing new law. ${ }^{157}$ This has led to a great deal of confusion about the reach of the new Commerce Clause. Even the Court's own discussion of its three-part Commerce Clause structure seems to lack clarity. For example, in Lopez, the Court cites Heart of Atlanta Motel, Inc. $v$. United States ${ }^{158}$ as a case

155 An exception to this may be the anticommandeering doctrine, which focuses on whether "Congress may use the States as implements of [federal] regulation." New York v. United States, 505 U.S. 144, 161 (1992); see also Printz v. United States, 521 U.S. 898, 935 (1997) (overturning a temporary provision of the Brady Handgun Violence Prevention Act, 44 U.S.C. $\$ \$ 921-931$ (2000), for requiring participation by state officials in the implementation of a federal regulation). However, this doctrine is limited to preventing Congress from requiring affirmative action on the part of the states. See id. at 935 ("Congress cannot compel the States to enact or enforce a federal regulatory program."). It does not appear to stop federal regulation or prohibition of state programs and is therefore beyond the scope of this Comment. See Reno v. Condon, 528 U.S. 141, 151 (2000) (sustaining congressional power to bar state motor-vehicle departments from disclosing personal information required for a driver's license or car registration).

${ }^{15013}$ Steven G. Calabresi, Federalism and the Rehnquist Court: A Normative Defense, 574 ANnals AM. ACAD. POL. \& SOC. SCI. 24, 25 (2001).

${ }^{157}$ Cf. United States v. Morrison, 529 U.S. 598, 637 (2000) (Souter, J., dissenting) ("Although a new jurisprudence has not emerged with any distinctness, it is clear that some congressional conclusions about obviously substantial, cumulative effects on commerce are being assigned lesser values than the once-stable doctrine would assign them."); Christy H. Dral \& Jerry J. Phillips, Commerce by Another Name: The Impact of United States v. Lopez and United States v. Morrison, 68 TENN. L. REv. 605, 616-17 (2001) ("With one hand the majority refuses to relinquish the rational basis test, while with the other hand the majority strikes down legislation with standards that clearly are stricter than rational basis.").

158 S7.S. 241 (1964). 
in the "channels" category. ${ }^{159}$ Then, in discussing the "substantial effects" category, the Court also cites Heart of Atlanta Motel as an example of a case "where we have concluded that the activity substantially affected interstate commerce." The "jurisdictional hook" that the Court implied might save statutes like the one in Lopez has also come under scrutiny as a confusing concept with the potential to become a tremendous loophole in the new Commerce Clause doctrine. ${ }^{161}$

Regardless of its possible shortcomings, however, it is clear that the Court is developing a new approach to Commerce Clause analysis, and, while there are no bright-line rules, the new approach has important and identifiable components. In particular, there is a sharp distinction between the way the Court will analyze economic activity and the way it will analyze noneconomic activity under the substantial effects test. ${ }^{162}$ If an activity is economic, regulation of that activity will be upheld, while if it is noneconomic, it will very likely be overturned. ${ }^{163}$

The Court has refrained from adopting any standard or test to determine whether an activity is economic or noneconomic and has noted how uncertain such an inquiry might be. ${ }^{1 ; 4}$ Nonetheless, it is clear that the idea of traditional state authority bears at least some relation to this determination. In his dissenting opinion in Morrison, Justice Souter implied that this was a key component for the Court:

The legitimacy of the Court's current emphasis on the noncommercial nature of regulated activity, then, does not turn on any logic serving the text of the Commerce Clause.... The essential issue is rather the strength of the majority's claim to have a constitutional warrant for its

159 United States v. Lopez, 514 U.S. 549,557 (1995).

160) Id. at 559.

${ }^{161}$ See generally Diane McGimsey, Comment, The Commerce Clause and Federalism After Lopez and Morrison: The Case for Closing the Jurisdictional-Element Loophole, $90 \mathrm{CAL}$. L. REV. 1675, 1680 (2002) (providing a detailed discussion of the jurisdictional hook and arguing that the "state-line crossing requirement does not impose meaningful limits on congressional regulation").

962 "While we need not adopt a categorical rule against aggregating the effects of any noneconomic activity in order to decide these cases, thus far in our Nation's history our cases have upheld Commerce Clause regulation of intrastate activity only where that activity is economic in nature." Morrison, 529 U.S. at 613.

${ }^{163}$ See supra Part II.A.1 (discussing Lopez and its distinction between economic and noneconomic activities).

${ }^{164}$ See Lopez, 514 U.S. at 566 ("Admittedly, a determination whether an intrastate activity is commercial or noncommercial may in some cases result in legal uncertainty."). 
current conception of a federal relationship enforceable by this Court through limits on otherwise plenary commerce power. ${ }^{165}$

Although the majority never identified precisely the importance of federalism in determining whether an activity is economic or not, it mentioned the issue repeatedly in its analysis.

Chief Justice Rehnquist discussed traditional state functions as part of his reasoning in both the Lopez and Morrison opinions. In Lo$p e z$, in particular, he focused on the idea that education is a traditional interest of the states as opposed to a commercial activity of some sort. ${ }^{166}$ This is noteworthy because a school is very much like a commercial enterprise except that it is run by the State. ${ }^{1 / 7}$ Rehnquist's reasoning seems to imply that State operation of a given endeavor weighs against a finding that the endeavor is commercial in Commerce Clause analysis.

Most remarkable is Justice Kennedy's concurring opinion in Lopez, in which he explicitly argued that if an activity is traditionally left to the states, then federal commerce power should be limited under the substantial effects test. ${ }^{\text {Ii\& }}$ In Commerce Clause analysis, says Justice Kennedy, "we must inquire whether the exercise of national power

${ }^{105} 529$ U.S. at 645 (Souter, J., dissenting).

${ }^{160}$ In dismissing Justice Breyer's dissent, in which Justices Stevens, Souter, and Ginsburg joined, Chief Justice Rehnquist noted:

Justice Breyer's rationale lacks any real limits because, depending on the level of generality, any activity can be looked upon as commercial. Under the dissent's rationale, Congress could just as easily look at child rearing as [commercial] .... We do not doubt that Congress has authority under the Commerce Clause to regulate numerous commercial activities that substantially affect interstate commerce and also affect the educational process. That authority, though broad, does not include the authority to regulate each and every aspect of local schools.

Lopez, 514 U.S. at 565-66; see also Morrison, 529 U.S. at 615-16 ("Petitioners' reasoning, moreover, will not limit Congress to regulating violence but may, as we suggested in Lopez, be applied equally as well to family law and other areas of traditional state regulation since the aggregate effect of marriage, divorce, and childrearing on the national economy is undoubtedly significant.").

${ }^{167}$ Indeed, in the Tenth Amendment context, the Court found that even a staterun school was a commercial enterprise. See Maryland v. Wirtz, 392 U.S. 183, 193 (1968) (holding that a publicly operated school is a commercial enterprise for purposes of regulating minimum wages and maximum hours).

${ }^{168}$ See Lopez, 514 U.S. at 577 (Kennedy, J., concurring) ("Were the Federal Government to take over the regulation of entire areas of traditional state concern, areas having nothing to do with the regulation of commercial activities, the boundaries between the spheres of federal and state authority would blur and political responsibility would become illusory."). 
seeks to intrude upon an area of traditional state concern." ${ }^{169}$ This approach draws on themes from the Court's Tenth Amendment cases but has significantly different implications. Instead of providing blanket immunity to states from Congress's otherwise valid exercise of Commerce Clause power, here the question of whether an activity is of traditional state concern directly impacts the Commerce Clause power inquiry itself. Although the extent of the relationship is not clear, it is certain that if an activity is traditionally regulated exclusively by the State, this will weigh in favor of a finding that Congress has exceeded its Commerce Clause authority.

\section{Private Medical Marijuana Distribution AND THE COMMERCE CLAUSE}

A medical marijuana challenge to the CSA would fall into the substantial effects category of Lopez. ${ }^{170}$ Medical marijuana advocates would first have to argue that the regulated activity is noneconomic. If successful, they would then need to refute Congress's contention that the intrastate regulation in question is necessary to the regulatory scheme. Such an inquiry would consider whether it is actually feasible for the government to distinguish between marijuana cultivated and used intrastate from that moved in interstate commerce, as well as what Congress's valid regulatory goal is and how that goal would be impacted if the class of intrastate activity in question could not be reached by Congress.

\section{A. The Controlled Substances Act}

The federal government currently criminalizes marijuana as part of the CSA's broad classification scheme. ${ }^{171}$ Controlled substances are

${ }^{169}$ Id. at 580 (Kennedy, J., concurring). Justice Kennedy argued that the Gun-Free School Zones Act of 1990 "foreclose[d] the States from experimenting and exercising their own judgment in an area to which States la[id] claim by right of history and expertise, and it $\mathrm{d}$ [id] so by regulating an activity beyond the realm of commerce in the ordinary and usual sense of that term." Id. at 583 (Kennedy, J., concurring). Justice Kennedy further observed, "Absent a stronger connection or identification with commercial concerns that are central to the Commerce Clause, [the regulation] contradicts the federal balance the Framers designed and that this Court is obliged to enforce." Id. (Kennedy, J., concurring).

${ }^{170}$ This is because medical marijuana advocates would use intrastate activity as a basis for such a challenge.

${ }^{171}$ See supra notes $46-51$ and accompanying text (discussing the enactment of the CSA). 
divided into five "Schedules," ${ }^{172}$ each with increasingly strict regulations. Marijuana is a Schedule I drug. ${ }^{173}$ Schedule I drugs are considered to have a high potential for abuse and no currently accepted medical use $\mathrm{e}^{17.1}$ and are therefore regulated in a prohibition model. Cocaine, in comparison, is a Schedule II drug, ${ }^{175}$ which means that it has a currently accepted medical use. ${ }^{176}$ A drug can be reclassified from one schedule to another only through the political process or by administrative action. ${ }^{177}$

Obviously, the CSA reaches a great deal of purely intrastate activity, particularly with respect to prohibition of simple possession. It is not uncommon for substances like marijuana or hallucinogenic mushrooms to be grown for personal use instead of interstate sale. Recognizing this fact, Congress enacted findings to help sustain the CSA against a potential Commerce Clause challenge. Congress observed, for example: "A major portion of the traffic in controlled substances flows through interstate and foreign commerce. Incidents of the traffic which are not an integral part of the interstate or foreign flow... nonetheless have a substantial and direct effect upon interstate commerce ...." Moreover, Congress found that "[c]ontrolled substances manufactured and distributed intrastate cannot be differentiated from controlled substances manufactured and distributed interstate. Thus, it is not feasible to distinguish, in terms of controls, between controlled substances manufactured and distributed interstate and controlled substances manufactured and distributed intrastate." 17:" Finally, Congress asserted that "[f]ederal control of the intrastate incidents of the traffic in controlled substances is essential to the effective control of the interstate incidents of such traffic."180 Congress used these findings to ground its power to regulate purely intrastate drug activities.

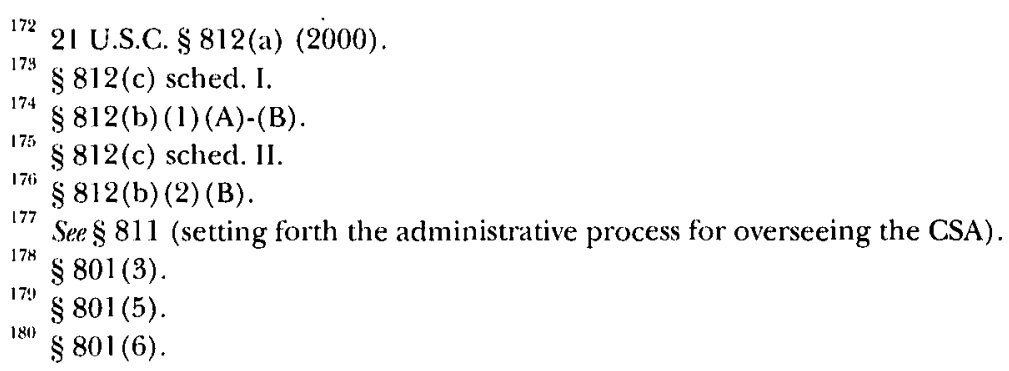




\section{B. Challenges Under Existing State Law}

A private medical marijuana dispensary operating legally under state law may try to challenge federal action against it by claiming Congress exceeded its Commerce Clause authority in passing the CSA. $^{181}$ An individual who cultivates medical marijuana for her personal use may make a similar challenge. For example, in Raich v. Ashcroft, filed in the Northern District of California in October 2002, the plaintiffs are two medical marijuana patients, Angel McClary Raich and Diane Monson, and two caregivers, John Doe Number 1 and John Doe Number 2. ${ }^{182}$ They are seeking an injunction to prevent enforcement of the CSA as a regulation of their medical-marijuanarelated conduct. $^{1 \times 3}$ John Doe Number 1 and John Doe Number 2 cultivate marijuana, which they provide to Raich, who is unable to cultivate it for herself, and which they grow using products manufactured in California exclusively. ${ }^{1 \$ 4}$ Monson grows marijuana for her own personal medical use. ${ }^{18 \pi}$ Though the personal-cultivation scenario is more likely to fall on the noneconomic line of a Lopez analysis, it is of little consequence practically.

Any medical marijuana challenge by private parties will almost certainly fail under the theory that their intrastate activity must be regulated as necessary for the enforcement of the CSA. ${ }^{186}$ Already, the district court in United States v. Cannabis Cultivators Club has held that a medical marijuana dispensary's activities were validly regulated under the commerce power. ${ }^{187}$ There, the Cannabis Cultivators Club (CCC) argued that its activity of providing marijuana to gravely ill persons for their medical use was outside the reach of the commerce power and could be distinguished from prior circuit cases upholding the CSA ${ }^{1 \mathrm{SH}}$ because (1) its activity was legal under state law and thus was not within the class of activities regulated by the CSA, and (2) its activity

${ }^{181}$ See Gaura, supra note 26 (reporting the Santa Cruz medical marijuana hospice's decision to sue the federal government for the return of confiscated marijuana under a Commerce Clause theory).

${ }^{182}$ Plaintiffs' Memorandum, supra note 27 , at 5.

188 Id. at $1-2$.

${ }^{184} I d$. at $5-6$.

${ }^{185}$ Id.

${ }^{186}$ United States v. Lopez, 514 U.S. 549, 561 (1995).

1875 F. Supp. 2d 1086, 1097-98 (N.D. Cal. 1998).

${ }^{188}$ See, e.g., United States v. Tisor, 96 F.3d 370, 374-75 (9th Cir. 1996) (holding, in a case decided after Lopez but before Morrison, that Congress's findings in the CSA were enough to ground its commerce power to enact the CSA). 
did not substantially affect interstate commerce. ${ }^{18 !}$ The court assumed that the activity was "within a different 'class of activities' from that which Congress expressly considered" and that the CCC's conduct in the particular instances before the court had no interstate effect. ${ }^{190}$ Nevertheless, the court rejected the CCC's argument because the activity was within a class-"non-profit distribution of medical marijuana" - that may have had a substantial effect on interstate commerce. $^{1.1}$ The court noted that the class of not-for-profit medical marijuana distribution was not one that was by its nature limited to intrastate activity, implying that regulation of the class was necessary to achieve the purposes of the CSA. ${ }^{1 ! 2}$ The court observed:

To hold that the Controlled Substances Act is unconstitutional as applied here would mean that in every action in which a plaintiff seeks to prove a defendant violated federal law, an element of every case-in-chief would be that the defendant's specific conduct at issue, based on facts proved at an evidentiary hearing or trial, substantially affected interstate commerce. 193

Thus, the court held that it was immaterial that the CCC's specific activities were intrastate since the class could be reached under the commerce power.

The court's reasoning in Cannabis Cultivators Club has been echoed by other courts in commerce-power challenges to federal drug laws that do not involve medical marijuana. The Fourth Circuit found that, since Lopez expressly reaffirmed the power to reach trivial activity under a general regulatory statute, it did not matter that the CSA "does not require the government to show that the specific conduct at issue substantially affected interstate commerce."194 This logic should also be controlling in Raich, where the plaintiffs are arguing that Congress lacks the authority to prohibit-or to allow the DEA to prohibit-their activity because it is purely noncommercial, intrastate ac-

[8!) Cannabis Cultizators Club, 5 F. Supp. 2d at 1097.

Isw Id. at 1097-98.

191 ld. at 1098 .

${ }_{192}$ See id. ("Medical marijuana may be grown locally, or out of the state or country, and there is nothing in the nature of medical marijuana that limits it to intrastate cultivation.").

193

${ }^{194}$ United States v. Leshuk, 65 F.3d 1105, 1112 (4th Cir. 1995); see also Proyect v. United States, 101 F.3d 11, 14 (2d Cir. 1996) ("The fact that certain intrastate activities within this class, such as growing marijuana solely for personal consumption, may not actually have a significant effect on interstate commerce is . . irrelevant."). 
tivity that has no effect on interstate commerce. ${ }^{19 i}$ "The activities for which Plaintiffs seek protection in this case are purely intrastate actions pursuant to valid California State law-the personal cultivation and personal use of cannabis for medical purposes by California citizens as recommended by the patients' physicians." gument, Congress can regulate the activity if it is essential to a broader regulation.

To determine if Congress needs to reach a certain class of activity to effectuate its broad regulation, one must consider the goal of the regulation. The relevant congressional goal is the prohibition of the interstate marijuana trade, whether medical or not. Since the general class of intrastate marijuana production is undoubtedly a part of the interstate drug trade, the class is an essential part of the valid regulatory goal. If Congress were not allowed to reach wholly intrastate private production of marijuana within this class, the CSA would be severely undercut. A court may then ask whether the plaintiff's activity is of a class that may be distinguished from the larger class of marijuana. However, the distinction does not seem feasible because the only way to determine whether a private actor is cultivating marijuana for intrastate medical use or interstate distribution is by making a caseby-case determination at trial. There is no easy statutory way to distinguish the categories.

Even if distinguishing private, nonprofit medical marijuana distribution operating legally under state law were feasible, it would likely undermine the regulatory scheme. For example, one might cultivate a large amount of marijuana, using some for intrastate medical purposes and some for interstate distribution. "In Northern California, Humboldt County officials said marijuana growers are allowed to grow hundreds of plants while claiming to be a medical caregiver to multiple patients, and no documentation is required." not reach medical cultivation permitted by state law, it would seriously undermine its ability to regulate that same person's cultivation for interstate distribution. Furthermore, the private, nonprofit distribution of medical marijuana is itself an interstate market, as there is no safe-

195 Plaintiffs' Memorandum, supra note 27, at 6-7.

I!ni Id. at 6.

1:17 Damny Freedman, Study: Most Medical Pot Users Older Men, AssoCIATEd PrEss ONLINE, Nov. 30, 2002, 2002 WL 103441487. For a general discussion of experiences with state medical marijuana programs, see U.S. GEN. ACCOUNTING OFFICE, MARIJUANA: EARLY EXPERIENCES WITH FOUR STATES' IAWS THAT ALLOW USE FOR MEdiCAL PURPOSES (2002), axailable at http://www.gao.gov/new.items/d03189.pdf. 
guard preventing a private actor from engaging in interstate medical distribution. Therefore, even the plaintiffs in Raich, who themselves are almost certainly engaged in purely intrastate noneconomic activity-going so far as to use only products manufactured in California for their cultivation-are unlikely to prevail on a Commerce Clause theory. A state-run program, however, may be more successful because of both the federalism concerns that underlie Lopez and Morrison and the reasons that allow Congress to reach purely intrastate commerce.

\section{SHOUld THE STATES GROW THEIR OWN?}

This Part analyzes a potential Commerce Clause argument on behalf of a state-run medical marijuana distribution program. ${ }^{198}$ The program would provide marijuana free of charge on a weekly or monthly basis to a patient suffering from a medical condition that meets the state's limited and well-defined list. The patient would be required to obtain and regularly renew a written doctor's recommendation clearly listing the accepted medical ailment. With the recommendation, and upon proof of state residence, the patient would receive a photo identification card. When filling the prescription at a distribution center, the patient would be required to show state identification that shared the same address as her identification card. To help ensure that the patient continued to reside within the state, the state would send stickers to this same address on a bimonthly basis that the patient would be required to place on her card. In order to cover the costs of this program, each patient would have to pay a bimonthly fee to keep her identification card valid and receive the stickers.

The marijuana would be grown by the state itself and distributed in cigarette form at state hospitals or police stations. ${ }^{\text {Although it }}$ would be more efficient for the state to adopt a program to test and distribute marijuana seized through the enforcement of state drug

${ }^{198}$ The framework of this theoretical program is based in part on ideas presented in initiatives in Arizona and San Francisco. For a discussion of Arizona's initiative, see ARIz. Legislative Council, Drug MEdicallzation, Prevention and CONTROL ACt OF 2002: ANALYSIS BY LEGISLATIVE COUNCIL (2002), auailable al http:// www.azleg.state.az.us/legtext/45leg/I1 12002DMPCA.pdf; for San Francisco's initiative, see Measure S: Medical Marijuana County of San Francisco, League of Women Voters of Cal. (Dec. 6, 2002), at http://www.smartvoter.org/2002/11/05/ca $/ \mathrm{sf} / \mathrm{meas} / \mathrm{S}$.

Each cigarette would contain a distinct label to unmistakably indicate it was part of the state program. 
laws, the jurisdictional-hook doctrine makes this system problematic. It is likely that Congress could prevent the implementation of this program, even in the face of a successful Commerce Clause challenge, simply by prohibiting distribution of marijuana that has at one time moved in interstate commerce. This would almost certainly cover a great deal of the seized marijuana and, even if there were substantial amounts of purely intrastate-seized marijuana, it would be prohibitively expensive for a state to determine which particular marijuana had ever traveled interstate and which had not. There are of course arguments that a jurisdictional hook would not reach a system using seized marijuana; ${ }^{200}$ however, the distinct possibility makes state cultivation the safest route for medical marijuana proponents. ${ }^{2(1)}$ For ease of discussion, this program, relying on state cultivation, will be referred to as the "State Program."

${ }^{2(6)}$ For example, one could argue that state seizure of marijuana removes the marijuana from commerce entirely, thus rendering the marijuana property of the state and negating any previous interstate movement. Similarly, the jurisdictional hook may not be enough in itself to ensure that there is a substantial effect on interstate commerce. For example, in United Siates v. Rodia, the Third Circuit held that a jurisdictional hook was not sufficient to place the statute in the substantial effects category. $194 \mathrm{~F} .3 \mathrm{~d} 465$, 473 (3d Cir. 1999). The court in Rodia considered a statute criminalizing the possession of child pornography that itself had not traveled in interstate commerce, but where the materials from which the pornography was created-Polaroid film-had so traveled. Id. at 468. The court found that precursors like the film or the developing chemicals were too tenuously related to the regulated activity to ground commerce power. Id. at 473. The court observed:

A hard and fast rule that the presence of a jurisdictional element automatically ensures the constitutionality of a statute ignores the fact that the connection between the activity regulated and the jurisdictional hook may be so attenuated as to fail to guarantee that the activity regulated has a substantial effect on interstate commerce.

Id. at 472 . Thus, the court adopted a rule that a "jurisdictional element is only sufficient to ensure a statute's constitutionality when the element either limits the regulation to interstate activity or ensures that the intrastate activity to be regulated falls within one of the three categories of congressional power," Id. at 473 . Under this rule, a system of distributing seized marijuana may well be safe from a "jurisdictionalhook" law.

201 This is not to say that a system distributing seized marijuana is not worth pursuing. In addition to being significantly less costly and more efficient than state-grown marijuana, it is probably more politically palatable than state-grown marijuana. It also might provide for a somewhat stronger argument that the activity is not economic. Seizing marijuana is a state police power, whereas marijuana cultivation may be considered more nearly economic. 


\section{A. Economic Versus Noneconomic}

As previous court cases have demonstrated, congressional power to implement its drug policies falls under the "substantial effects" category of Lopez and Morrison. ${ }^{202}$ The most important question in a "substantial effects" analysis is whether the class of activity under the State Program is economic in nature or whether it is a noneconomic activity traditionally left to the states. ${ }^{203}$ The Court has not announced a standard or test for making this determination. Indeed, Chief Justice Rehnquist has said, "Admittedly, a determination whether an intrastate activity is commercial or noncommercial may in some cases result in legal uncertainty." mulate a precise answer to the question, comparing the State Program with the discussion in Lopez and Morrison indicates that there is a strong claim that the activity is not economic.

The State Program's marijuana distribution is certainly not economic activity in the strictest sense of the word, as the primary purpose of the program is not to make money but to provide for the health of the state's citizens. Nevertheless, this alone might not be enough to place the State Program on the noneconomic side of the line. The Lopez Court noted that Wickard, which upheld regulation of wheat cultivation for in trastate use, ${ }^{205}$ "involved economic activity in a way that the possession of a gun in a school zone does not." ${ }^{\text {2016i }}$ At first glance, this may be taken to mean that cultivation is a commercial activity, ${ }^{207}$ but a closer reading of the majority's reasoning reveals that the Court did not make this finding.

The Court's statement in Lopez that the activity in Wickard had an economic link seems to stand merely for the proposition that noneconomic intrastate activity may be regulated if it is essential to a broader economic interstate regulation. This interpretation is the most logical for two reasons. First, the majority's explanation of

${ }^{202}$ See, e.g., United States v. Cannabis Cultivators Club, 5 F. Supp. 2d 1086, 1097-98 (N.D. Cal. 1998) (analyzing a medical marijuana challenge under the "substantial effects" doctrine), rev'd sub nom. United States v. Oakland Cannabis Buyers' Coop., 190 F.3d 1109 (9th Cir. 1999) (per curiam), ret'd, 532 U.S. 483 (2001).

2013 See supra Part II.A (discussing the Court's approach to substantial effects).

${ }^{204}$ United States v. Lopez, 514 U.S. 549, 566 (1995).

205 Wickard v. Filburn, 317 U.S. 111 , 125 (1942).

2006 Lopez, 514 U.S. at 560.

${ }^{207}$ In dissenting from the Lopez majority, Justice Breyer noted that the Court in Wickard expressly found that homegrown wheat consumption was not a commercial activity. II. at 628 (Breyer, J., dissenting). 
Wickard's economic link focused exclusively on the fact that the wheat production obstructed the purposes of a larger economic regulation. ${ }^{208}$ The Court noted that the Act at issue in Wickard "was designed to regulate the volume of wheat moving in interstate and foreign commerce" and then recounted the Wickard Court's finding that the regulation of intrastate production of wheat was necessary to effectuate that congressional purpose. ${ }^{209}$ The Court concluded its discussion by finding that "[s]ection 922 (q) is not an essential part of a larger regulation of economic activity, in which the regulatory scheme could be undercut unless the intrastate activity were regulated," and cannot therefore be upheld under the aggregation doctrine of Wickard. ${ }^{211}$ Second, the Wickard Court clearly stated that the wheat production in question was not commercial. ${ }^{21}$ The Lopez Court surely was not ignorant of this fact, ${ }^{212}$ and it is equally unlikely that it would substitute its own view for the Wickard Court's factual finding, particularly given some of the Justices' professed aversions to judicial activism. ${ }^{213}$ Therefore, the State Program would not be considered economic under Wickard simply because it involves cultivation or distribution.

At the same time, the Court's reasoning with regard to Wickard does not necessarily mean the State Program would be considered

${ }^{208}$ See id. at 560-61 (observing that the Agricultural Adjustment Act of 1938, 7 U.S.C. $\$ \$ 1281-1393$ (2000), was designed to avoid surpluses and shortages of wheat in order to stabilize prices and noting that home-grown and home-consumed wheat would hamper such a purpose).

${ }^{209} I d$. at 560 ; see also Wickard, 317 U.S. at 128 (noting that "[h]ome-grown wheat ... competes with wheat in commerce").

210 Lopez, 514 U.S. at 561.

211 See Wickard, 317 U.S. at 125 (holding that Congress could regulate home-grown wheat production, even "though it may not be regarded as commerce"). finding

${ }_{212}$ As indicated suprn note 207 , Justice Breyer in dissent specifically noted this

${ }^{213}$ See, e.g., Antonin Scalia, Originalism: The Lesser Evil, 57 U. CIN. L. REV. 849, 863 (1989) ("[T] he main danger in judicial interpretation of the Constitution-or, for that matter, in judicial interpretation of any law-is that the judges will mistake their own predilections for the law."); see also Randy E. Barnett, Is the Rehnquist Court an "Activist" Court? The Commerce Clause Cases, 73 U. CoL.O. I. REV. 1275, 1281 (2002) ("[W] hile the Rehnquist court may indeed be an activist court in its method, the results it has reached are less activist than those of previous courts in precisely those cases where its activism is now being criticized-most especially in its Commerce Clause decisions."). But see Christopher E. Smith \& Avis Alexandria Jones, The Rehnquist Court's Activism and the Risk of Injustice, 26 CONN. L. REv. 53, 57 (1993) (arguing that the Rehnquist Court is an activist court despite the Justices' claims of believing in "judicial conservatism"). While the question of whether the Rehnquist Court is an activist court is the subject of much debate, for purposes of this Comment it is sufficient to note that this is not how the conservative Justices of the Court view themselves. 
noneconomic, especially since cultivation and distribution are ordinarily done in conjunction with economic enterprises. A key question in this close case would be whether this cultivation and distribution is part of an activity traditionally left to the states. ${ }^{214}$ Here, the cultivation and distribution are part of a state health program that does not aim to make money for the state. Furthermore, the federal government itself does not regulate marijuana activities as if they were economic; rather, they are regulated as criminal and health related. According to the CSA, the scheduling of marijuana is based entirely on health considerations, and, as a Schedule I substance, essentially all marijuana activity is criminal. ${ }^{215}$

Both health and criminal activities are traditionally within state domain. In Lopez, the Court reiterated: "“States possess primary authority for defining and enforcing the criminal law.","216 "It went on to criticize the GFSZA because its "prohibitions apply even in States that have chosen not to outlaw the conduct in question.",217 This is particularly relevant here, as the federal government's regulation would outlaw a program that the state determined to be necessary for the health of its citizens. ${ }^{218}$ The state's traditional power over health is

${ }^{214}$ See supra Part II.C (discussing the importance of federalism principles in recent Commerce Clause cases).

${ }^{215}$ There are limited exceptions, such as marijuana use by the remaining Compassionate IND patients, see supra text accompanying notes 56-59 (describing the Compassionate IND program), or in highly regulated scientific studies, see 21 U.S.C. $\$ 823$ (2000) (allowing the use of Schedule I substances in a strictly controlled research project registered by the Secretary of Health and Human Services in conjunction with the Attorney General).

211 Lopez, 514 U.S. at 561 n.3 (quoting Brecht v. Abrahamson, 507 U.S. 619, 635 (1993) (quoting Engle v. Isaac, 456 U.S. 107, 128 (1982))).

217 Id. (quoting the government's brief).

${ }^{218}$ Judge Kozinski's concurrence in Conant v. Walters, 309 F.3d 629 (9th Cir. 2002), although in the context of a private scheme, nicely explains the implications for federalism principles in this type of situation. In Conant, the federal government sought to effectively prevent California from implementing its medical marijuana law by stopping doctors from recommending marijuana to their patients. Id. at 632-33; see supra text accompanying notes 79-81 (discussing the Ninth Circuit's decision). Judge Kozinski argued that while "[f]ederal efforts to regulate [medical marijuana] considerably blur the distinction between what is national and what is local," "allowing the federal government, already nearing the outer limits of its power, to act through unwilling state officials would "obliterate the distinction' entirely." Conant, 309 F.3d at 647 (Kozinski, J., concurring) (quoting Lopez, 514 U.S. at 557). These same federalism concerns are even stronger in considering the problem of the State Program. Judge Kozinski found the federal government's indirect interference with California law "[ran] afoul" of federalism principles that limit how Congress "may use the power it has." Id. at 645,647 (Kozinski, J., concurring). With the State Program, the federal government 
likewise widely recognized. States may enact civil commitment schemes $^{219}$ or mandatory vaccination programs ${ }^{220}$ to provide for the health of their citizens. Justice Kennedy has argued that there is "substantial authority allowing the State to take sides in a medical debate, even when fundamental liberty interests are at stake and even when leading members of the profession disagree with the conclusions drawn by the legislature."221 Furthermore, the Court has noted that a state could completely prohibit the use of Schedule II drugs, which are allowed for medical use under federal law, ${ }^{222}$ because of its broad power over health regulations. ${ }^{223}$ Particularly relevant here is the Court's theory that when "Congress undertakes to act in areas fraught with medical and scientific uncertainties, legislative options must be especially broad.",224

Though it is impossible to be certain given the lack of standards provided by the Court, many of the factors that lead the Court to strike down the statutes in Lopez and Morrison point to a similar conclusion. The State Program is a not-for-profit health-care activity, and there can be little dispute that, to the extent traditional areas of state authority can be defined, health and criminal law are among them. As Justice Kennedy noted, the Court has a "particular duty to ensure that the federal-state balance is not destroyed" when Congress seeks to encroach upon state prerogative in traditional areas of state concern. $^{22.5}$ In view of these considerations, and particularly the lack of guidance from the Court on how to decide the economic question, to

would seek not merely to make implementation of the State Program more difficult, but to forbid it entirely.

${ }^{219}$ See Kansas v. Hendricks, 521 U.S. 346, 357 (1997) ("We have consistently upheld such involuntary commitment statutes....). Civil commitment entails the "forcible civil detainment of people who are unable to control their behavior." Id.

${ }^{220}$ See Jacobson v. Massachusetts, 197 U.S. 11,38 (1905) (holding that it was a valid exercise of the state's police power to enact a statute requiring vaccination).

${ }^{221}$ Stenberg v. Carhart, 530 U.S. 914, 970 (2000) (Kennedy, J., dissenting).

${ }^{222}$ See 21 U.S.C. $\$ 829($ a) $(2000)$ (permitting prescriptions of Schedule II substances).

${ }^{223}$ See Whalen v. Roe, 429 U.S. 589,603 n.30 (1977) ("It is, of course, well settled that the State has broad police powers in regulating the administration of drugs by the health professions.").

${ }^{224}$ Jones v. United States, 463 U.S. 354, 370 (1983) (quoting Marshall v. United States, 414 U.S. 417,427 (1974)).

U2:5 United States v. Lopez, 514 U.S. 549, 581 (1995) (Kennedy, J., concurring); see also id. at 583 (Kennedy, J., concurring) ("The [GFSZA] forecloses the States from experimenting and exercising their own judgment in an area to which States lay claim by right of history and expertise, and it does so by regulating an activity beyond the realm of commerce in the ordinary and usual sense of that term."). 
move to the next step in the Commerce Clause inquiry it is sufficient to say that the most relevant factors seem to weigh heavily toward a noneconomic finding, while few factors would indicate that the State Program is an economic endeavor.

\section{B. Essential to Larger Economic Regulation?}

Once placed in the noneconomic category, the most important question is whether the activity can still be sustained as an essential part of a larger valid economic regulation. This is particularly the case after the Court's decision in Morrison, in which the Court demonstrated that even in the face of congressional findings clearly showing the substantial impact of the intrastate noneconomic conduct on interstate commerce, the Court will almost certainly refrain from aggregating the purely intrastate conduct in question. ${ }^{226}$ Therefore, the "essential to the regulation" theory is the only currently accepted basis for regulating noneconomic intrastate activity under the Commerce Clause. $^{227}$

The standard for determining whether a noneconomic intrastate activity is essential to a larger economic regulation is even more uncertain than that for answering the economic activity question. The Court has not had occasion to apply this theory in its recent holdings or in pre-Lopez holdings, where all commerce regulations were routinely upheld under rational basis scrutiny. ${ }^{228}$ Nevertheless, the relevant factors in this inquiry are largely self-evident. Unlike the broad question of whether an activity is economic, the question of whether a given intrastate activity is essential to a valid economic regulation is necessarily confined to a very specific relationship.

In considering whether a given intrastate activity falls under this exception, one must first determine the intrastate activity (as a class) and the valid congressional regulatory goal. The regulatory goal must be legitimate, or Congress could reach any activity simply by stating that a goal required regulation of that activity. For example, Lopez's activity was undoubtedly essential to a broad regulation of gun posses-

226) See United States v. Morrison, 529 U.S. 598, 613 (2000) ("While we need not adopt a categorical rule against aggregating the effects of any noneconomic activity[,] . . . our cases have upheld Commerce Clause regulation of intrastate activity only where that activity is economic in nature.").

${ }^{227}$ It should be reemphasized that the Court has stopped short of announcing a bright-line rule against aggregation of noneconomic activity. Id.

${ }_{228}$ See supra Part II.A (discussing pre-Lopez Commerce Clause doctrine). 
sions near a school, but such a goal is not an interstate goal and, therefore, is not legitimate.

In this instance, the class of activity is best defined as "state distribution of medical marijuana." Marijuana regulation prohibits the interstate marijuana trade in order "to deal in a comprehensive fashion with the growing menace of drug abuse in the United States." ${ }^{229}$ To determine if regulation of the State Program is essential to this regulatory scheme, one should first ask whether it is feasible to distinguish between the purely intrastate class in question and other, broader classes of activity covered by the regulation. If the government is not able to make this distinction easily, and there is valid power to regulate the broader class, regulation of the intrastate activity is essential to achieve the goal since requiring a burdensome case-by-case finding would undermine the regulation. Even if it is feasible for the government to distinguish the intrastate activity, it may fall under the "essential to a broader regulation" exception. It would be impossible to. achieve the goal of increasing the national price of a commodity, for example, without regulating all production of that commodity.

First, it is feasible to distinguish the class of activity governed by the State Program from the broader regulated class. Although Congress found that intrastate substances "cannot be differentiated from controlled substances manufactured and distributed interstate," conclusory statement is not true for the State Program. The Program involves a clearly defined and limited group of actors engaged in the specific activity of cultivating and dispensing medical marijuana. In addition, the Program's provisions, like the one requiring that dispensed cigarettes should be clearly marked to indicate that they are part of the State Program, help ensure that the intrastate class of activity is easy to distinguish. The contrast with private medical marijuana cultivators is particularly stark here. In United States v. Cannabis Cultivators $C l u b$, the court found that "[m]edical marijuana may be grown locally, or out of the state or country, and there is nothing in the nature of medical marijuana that limits it to intrastate cultivation." Here, the State Program is by its nature limited to in-state activity and distinguishable from private marijuana-related activity.

${ }^{222}$ H.R. REP. NO. 941444, at 1 (1970), reprinted in 1970 U.S.C.C.A.N. $4566,4567$.

21 U.S.C. $\$ 801(5)(2000)$.

${ }^{231} 5$ F. Supp. 2d 1086, 1098 (N.D. Cal. 1998), rev'd sub nom. United States v. Oakland Cannabis Buyers' Coop., 190 F.3d 1109 (9th Cir. 1999) (per curiam), rev'd, 532 U.S. 483 (2001). 
With this hurdle passed, the actual relationship between the State Program and Congress's regulatory goal must be examined. Congress has found that intrastate marijuana activity is essential to interstate enforcement because, "after manufacture, many controlled substances are transported in interstate commerce, [and] controlled substances distributed locally usually have been transported in interstate commerce immediately before their distribution."

Congress's contention that it is essential to regulate the class of activity does not necessarily make the regulation essential. ${ }^{298}$ The pertinent question is what impact the State Program, if left outside congressional reach, would have on Congress's larger regulation. In Wickard, the Court was able to reach wheat production because, if the class of wheat production was left unregulated, it would severely undermine the regulatory goal ${ }^{234}$ - "the goods at issue ... were being substituted for the interstate wheat that the statute attempted to regulate." ${ }^{2: 35}$ In contrast, statutes that criminalize gun or drug possession involve a different sort of economic analysis. ${ }^{236}$ Here, the CSA does not seek to control the price of marijuana but rather to prevent its interstate distribution entirely.

Some of the CSA's findings to ground commerce power over intrastate activity are immediately inapplicable. For example, the State Program's marijuana will have been grown intrastate and not obtained

${ }^{232} \$ 801(3)(\mathrm{A})-(\mathrm{B})$

2334 See United States v. Morrison, 529 U.S. 598, 614 (2000) ("[T]he existence of congressional findings is not sufficient, by itself, to sustain the constitutionality of Commerce Clause legislation. .. " "Simply because Congress may conclude that a particular activity substantially affects interstate commerce does not necessarily make it so."' (quoting United States v. Lopez, 514 U.S. 549, 557 n.2 (1995) (quoting Hodel v. Va. Surface Mining \& Reclamation Ass'n, 452 U.S. 264, 311 (1981) (Rehnquist, J., concurring)))).

See Wickard v. Filburn, 317 U.S. 111, 128 (1942) ("One of the primary purposes of the Act ... was to ... limit the volume [of wheat] that could affect the market. It can hardly be denied that a factor of such volume and variability as home-consumed wheat would have a substantial influence on price and market conditions.").

${ }^{235}$ United States v. Rodia, 194 F.3d 465, 476 (3d Cir. 1999).

${ }^{236}$ As the Third Circuit explained:

[M] any courts have applied the Wickard principle to criminal statutes, concluding that suppressing the intrastate demand for a good (for example, by criminalizing possession of guns or drugs) would have a substantial impact on interstate commerce by affecting the supply of that good. In many cases, this will be a reasonable assumption. We note, however, that [this] economic model is different from Wickard's substitution analysis, a fact that many courts have glossed over.

ld. at 477 (citations omitted). 
through interstate commerce. ${ }^{937}$ The Program may nevertheless undermine the CSA by contributing to the swell in marijuana activity ${ }^{298}$ or because valid in-state medical users may attempt to bring their marijuana across state lines for sale or personal use. ${ }^{239}$ While the first point may be disputed, ${ }^{240}$ it is inevitable that at least some minimal number of patients will travel across state lines with marijuana obtained through the State Program. The Court has provided no clear guidelines for determining whether this fact is enough to "undermine" the criminalization of interstate marijuana activity. The fact that some of the intrastate activity has a direct tie to interstate activity will not always provide Commerce Clause authority; in Lopez, for example, certainly some of the guns that were regulated, and probably the vast majority of them, had moved in interstate commerce at one time or another. Still, the Court might find that Congress has a particularly pressing interest in ensuring that marijuana is not taken across state lines, and so even minor incidents would be enough to undermine the broad scope of the CSA.

\section{CONCLUSION}

Though the ambiguity of the current "substantial effects" doctrine makes a clear analysis difficult, a number of factors indicate that a state-run medical marijuana program would have a strong Commerce Clause argument against federal regulation. A state-run medical marijuana program would implicate federalism principles that leave traditional authority over health care and criminal law to the states. A state-run program's activity would also be easily distinguishable from the general marijuana trade, which is vital to the consideration of whether the program's activities are "essential" to a larger regulation. At the same time, the lack of clarity in current Commerce Clause ju-

${ }^{297}$ Cf. 21 U.S.C. $\$ 801$ (3) (B) (2000) (“[C]ontrolled substances distributed locally usually have been transported in interstate commerce immediately before their distribution ....").

${ }^{238}$ See $\$ 801$ (4) ("Local distribution and possession of controlled substances contribute to swelling the interstate traffic in such substances.").

${ }^{233}$ See $\$ 801(3)(\mathrm{A}),(\mathrm{C})$ ("[A]fter manufacture, many controlled substances are transported in interstate commerce,... [and] controlled substances possessed commonly flow through interstate commerce immediately prior to such possession.").

${ }^{240}$ The congressional findings on this point likely refer to the fact that, in the private market, increased local demand and sale of marijuana will lead to a swell in interstate traffic to meet the demand. This concern does not seem to apply here. In fact, one might argue that the State Program reduces the interstate trade in marijuana by providing a purely intrastate source for medical users. 
risprudence may itself weigh against medical marijuana advocates hoping to make this challenge. Given the political considerations in play, the Court may well use this leeway to allow for medical marijuana to be analyzed differently than other activities. Commentators and attorneys already refer to a "drug exception" to the Fourth Amendment," insinuating that the Justices' political and personal feelings about drugs might color their legal holdings. Nonetheless, given the continued hostility toward medical marijuana on the part of federal elected officials, a Commerce Clause challenge to regulation of a state-run distribution program is currently the best strategy available to patients who seek a system of legal medical marijuana distribution. In addition to the potential for success in the legal world, implementing a state-run system would also put additional political pressure on the federal government, forcing it to enforce federal law by suing the states themselves-not private clubs.

${ }^{241}$ See Steven Wisotsky, Crackdown: The Emerging "Drug Exception" to the Bill of Rights, 38 HASTINGS L.J. 889, 909-10 (1987) (noting that "defense lawyers have begun to joke nervously about the "drug exception to the $[\mathbf{F}]$ ourth $[A]$ mendment"). 